\title{
MOTIVATIONAL INSTRUCTIONAL SKILLS FOR IMPROVING TEACHING AMONG TEACHERS OF PRIMARY SCHOOL PUPILS
}

\section{ELIZABETH N. EBIZIE, CHARLES A. ORAELOSI* \& MKPOIKANKE SUNDAY OTU}

Department of Educational Foundations, University of Nigeria, Nsukka, Enugu State, Nigeria

\begin{abstract}
This study was carried out to investigate the primary school teachers' perceived motivational instructional skills needed for improving teaching and learning in Enugu State, Nigeria. Descriptive survey design was adopted for the study. The study sample was 1,196 teachers, comprising of 579 males and 617 female teachers. Multistage sampling technique was used in the selection of the sample size. The instrument used for data collection was 'Perceived Motivational Instructional Skills Needed for Teaching' Questionnaire' abbreviated (PMISNTQ). Using Cronbach Alpha method, the instrument had an internal consistency coefficients of 0.87 . The instrument was administered to the participants in their respective schools. The data collected were analyzed using mean, standard deviation and t-test statistics and the hypotheses was tested at 0.05 level of significance. Findings revealed that the motivational skills needed by the teachers are: attributing pupils' successes to their (pupils') effort; encouraging pupils to always try their best in class work and informing pupils that they can always do well in class work. Furthermore, the hypotheses tested in the study revealed that there is no statistically significant difference in the mean rating of male and female teachers on the perceived instructional skill needs of teachers for improved teaching. The skills discussed in this study should be integrated into the teacher education curriculum as a separate course that students must credit before certificate of teaching could be awarded to them.
\end{abstract}

KEYWORDS: Motivation, Instructional Skills, Improvement, Teaching, Enugu State \& Nigeria

Received: Jun 06, 2020; Accepted: Jun 26, 2020; Published: Aug 18, 2020; Paper Id.: IJMPERDJUN2020805

\section{INTRODUCTION}

Motivation is related to other concepts such as drives, needs, wants and ambitious among others. Motivation has to do with the internal state or mental and psychological set in an individual which compels, energizes, sustains and directs the individual's activity toward a goal (Ngwoke, 2009). The author also defined motivation as a psychological construct which explains purposive or goal-directed behaviour in human beings. In agreement, Agbo (2012) stated that motivation is important in learning because it is present naturally in pupils and it is the force that helps them to achieve their learning goals. Similarly, Wilen, Hutchison and Ishler (2008) concurred that motivation is the cornerstone of instruction. Thus without it, it will be difficult for pupils to learn successfully. To this end, motivation is important and influential in producing favorable learning activities and attitudes. For example, when children have strong motivation in learning, it will generate interest and positive attitudes that will enhance their desire and performance, but the reverse is the case if motivation is lacking. Also, lack of motivation can cause lack of interest in learning which can affect the performance of pupils in learning. What is required, therefore, is motivation to help drive interest towards meaningful and successful learning in the classroom. Gleaning from the foregoing, motivation, no doubt, produces and sustains the energies that pupils require to succeed in learning. Consequently, teachers need to search for and use different motivational skills to promote effective teaching and learning in the classroom.

Motivational skills include personal characteristics that help teacher to focus and maintain learners' energies 
towards goal-directed activities (Zwick, 2007). Motivational skills are personal characteristics that teachers utilize to help pupils to learn and improve teaching in the primary schools. This implies that motivational skills are those skills and activities of the teacher which are geared towards creating and sustaining the learners' zeal to undertake goal-directed activities for effective learning. This means that if pupils are properly motivated, it implies that teachers are well equip with motivational instructional skills that in turn promote effective teaching. It compels, energizes, sustains and directs pupils' activity toward a goal. That is to say, motivational instructional skills facilitate teaching and learning in tremendous ways.

Motivational instructional skill is defined as a skill the teachers use in influencing or stimulating pupils to take action that will accomplish a desired goal. Motivational instructional skills are the inner drive inherent in teachers which enable them to effectively stimulate the learner towards achievement of their common desired goals of learning (Mondy, Holmes \&Flippo, 2011). This definition tends to define motivational instruction skill in terms of goal-directed behaviour. This implies that behaviour has an origin which terminates when the goal is achieved. Motivational instructional skill is a strong quality that primary school teachers must possess in order to successfully meet the needs of the pupils.

Moreover, research evidences indicated that motivational instruction skills include: catering for the pupils' learning needs, creating an inclusive classroom atmosphere which they can feel respected and connected and developing positive attitudes by relating what is taught with what obtains in their environment, maintaining an active involvement of pupils in learning, valuing what they like to do and encouraging them to it, solving challenging problems, playing simple games, maintaining eye to eye contact, speaking aloud, using handshakes, head nods and so on. Meanwhile, Imo, Ekpenyong and Akpan (2014) found that students perceived that teachers' motivational skill is low and Muhammand and Zaki (2010) posited that cooperative instructional strategy can be used to improve students' performance. However, it is not clear from the literature whether gender influence the perception of teachers regarding motivational instructional skills.

For instance, Keller (2011) has noted that gender could mar teaching. Mean while, Obasi (2009) perceived gender as many social and cultural constructed characteristics, qualities, behaviour and roles which different societies ascribe to male and female. Thus, there are behaviours meant for males and there are the ones meant for females. In line with this, Onyeke (2013) suggested that male teachers and female teachers are likely to differ in their kind of motivational instructional skills. Nwafor (2013) opined that female teachers are more likely to discriminate than the male teachers in teaching in the classroom. Jacklin and Lacey (2007) concurred that male teachers exhibit good organizational and grouping strategies than their female counterparts. It is against this background that the present study seeks to also ascertain the gender differences on motivational instructional skills of teachers. Questions, such as (1) "What are the motivational instructional skills needed by primary school teachers for improving teaching? and (2) What are the mean responses of male and female teachers on the motivational instructional skills needed for improving teaching?" were answered in this study. Also, the researchers tested the hypothesis which states that "there is no significant difference in the mean rating of male and female teachers on the motivational instructional skills needed for improved teaching".

\section{METHODS AND MATERIALS}

The study adopted a descriptive survey design to investigate the perceived instructional skill needs of primary school teachers for improved teaching in Enugu State. According to Ali (2006) descriptive survey design is concerned with describing events as they are, without any manipulation of what caused the event or what is being observed. The study was carried out in Enugu State with 1196 which consists of 579 male and 617 female primary school teachers drawn through multistage sampling technique. 
The instrument for data collection was a questionnaire titled "Perceived Motivational Instructional Skill Needed for Teaching Questionnaire" (PMISNTQ). The questionnaire consists of two sections. Section A and Section B. Section A comprised information regarding the personal data of primary school teachers such as gender, location and education zone. Section B contained items that measure motivational instructional skills. A four-point rating scale was provided for the respondents to indicate the strength of their opinion as follows: Strongly Agree (SA) $=4$, Agree $(A)=3$, Disagree $(D)=2$ Strongly Disagree $(\mathrm{SD})=1$ for the clusters.

The instrument was subjected to face validation by three experts in a University in Nigeria. The experts were asked to add or remove any item of the instrument that they considered not useful to the study. Thereafter, the final version of the instrument was trial tested on a sample of 30 (teachers).The analysis of data yielded Alpha co-efficient estimate value of 0.80. This high co-efficient estimate value reveals that the instrument is reliable to be used for the study. The choice of subjecting the items to Cronbach Alpha statistical analysis was based on the fact that the items are homogeneous and not dichotomously scored.

The instrument was administered to the teachers who took part in the study and the data collected were analyzed using mean and standard deviation. In taking a decision in each of the research questions, mean scores of 2.50 and above on the four-point rating scale was considered acceptance, while those below 2.50 was regarded as rejection. The t-test statistics was employed to test the null hypothesis at 0.05 level of significance.

\section{RESULTS}

Table 1: Mean Responses of Primary School Teachers on the Motivational Instructional Skill Needs for Improved Teaching (N-1196)

\begin{tabular}{|c|l|c|l|l|}
\hline S/N & \multicolumn{1}{|c|}{ TTEMS } & \multicolumn{1}{|c|}{ Teachers Need to: } & SD & \multicolumn{1}{|c|}{ RMK } \\
\hline & \multicolumn{1}{|c|}{} & \\
\hline 1 & Attribute pupils' successes to their (pupil's) effort & 3.26 & .722 & Agree \\
\hline 2 & Call pupils by their first names to show sign of recognition. & 3.26 & .883 & Agree \\
\hline 3 & Encourage pupils to always try their best in class work. & 3.30 & .991 & Agree \\
\hline 4 & Inform pupils that they can always do well in class work. & 3.29 & .748 & Agree \\
\hline 5 & Use gifts to encourage pupils who perform well in class. & 3.29 & .605 & Agree \\
\hline 6 & Move around the class and approach all pupils while teaching. & 3.28 & .963 & Agree \\
\hline 7 & Respond positively to incorrect answers, but identify correct parts. & 3.29 & .806 & Agree \\
\hline 8 & Be friendly to only pupils who are brilliant in class. & 1.49 & .829 & Disagree \\
\hline 9 & Ask erring pupils in the classroom to do extra work as punishment. & 1.52 & .777 & Disagree \\
\hline 10 & Motivate bright pupils by allowing them to teach other classmates. & 3.28 & .914 & Agree \\
\hline & Grand mean & $\mathbf{2 . 9 2}$ & $\mathbf{0 . 8 2}$ & Agree \\
\hline
\end{tabular}

Table 1above presents the mean responses of teachers on motivational instructional skills needs of teachers for improved teaching. From the analysis on the table, the respondents agreed on eight out of the ten items on the list. The respondents did not agree that being friendly to only pupils who are brilliant in class is a good motivational instructional skill. Similarly, the respondents disagreed that asking erring pupils in the classroom to do extra work as punishment is a motivational instructional skill. The disagreement of the respondents on the above items is obvious, because, no teacher with motivational skill will be friendly to pupils who are brilliant in class alone. Otherwise, those that are not brilliant may be demotivated to learn. In addition, asking erring pupils in the classroom to do extra work as punishment may not improve their teaching ability.

In addition to this analysis, the cluster mean for the items listed, which indicates agreed is 2.92 . This implies that 
the respondents agreed on the motivational instructional skills need of teachers for improved teaching in Enugu State.

Table 2: Mean Responses of Male and Female Teachers on the Motivational Instructional Skills Needed for Improved Teaching (N-1196)

\begin{tabular}{|c|l|c|c|c|c|c|l|}
\hline S/N & \multicolumn{1}{|c|}{\begin{tabular}{c}
\multicolumn{1}{|c|}{ ATEMS a Teacher, One Need to: } \\
\multicolumn{1}{|c|}{$\begin{array}{c}\text { Males } \\
\text { SD }\end{array}$}
\end{tabular}} & \multicolumn{1}{c|}{ RMK } & \multicolumn{2}{c|}{$\begin{array}{c}\text { Females } \\
\text { SD }\end{array}$} & \multicolumn{1}{c|}{ RMK } \\
\hline 1 & Attribute pupils' successes to their (pupil's) effort & $\overline{\mathbf{X}} 31$ & 1.00 & Agree &.$\overline{\mathrm{X}} 0$ & 1.03 & Agree \\
\hline 2 & Call pupils by their first names to show sign of recognition. & 3.48 & 0.88 & Agree & 3.39 & 0.90 & Agree \\
\hline 3 & Encourage pupils to always try their best in class work. & 3.45 & 0.86 & Agree & 3.36 & 0.88 & Agree \\
\hline 4 & Inform pupils that they can always do well in class work. & 3.25 & 0.94 & Agree & 3.28 & 0.87 & Agree \\
\hline 5 & Use gifts to encourage pupils who perform well in class. & 3.22 & 0.95 & Agree & 3.26 & 0.91 & Agree \\
\hline 6 & Move around the class and approach all pupils while teaching. & 3.17 & 1.05 & Agree & 3.25 & 0.98 & Agree \\
\hline 7 & $\begin{array}{l}\text { Respond positively to incorrect answers, but identify correct } \\
\text { parts. }\end{array}$ & 3.31 & 0.65 & Agree & 3.26 & 0.59 & Agree \\
\hline 8 & Be friendly to only pupils who are brilliant in class. & 1.48 & 0.88 & Disagree & 1.39 & 0.90 & Disagree \\
\hline 9 & $\begin{array}{l}\text { Ask erring pupils in the classroom to do extra work as } \\
\text { punishment. }\end{array}$ & 1.45 & 0.86 & Disagree & 1.36 & 0.88 & Disagree \\
\hline 10 & $\begin{array}{l}\text { Motivate bright pupils by allowing them to teach other } \\
\text { classmates. }\end{array}$ & 3.25 & 0.94 & Agree & 3.28 & 0.87 & Agree \\
\hline
\end{tabular}

Data on table 2 above show the mean ratings of male teachers and female teachers in respect to motivational instructional skills needed for improved teaching in Enugu state. From the analysis, the male and female teachers in Enugu State both agreed on the same items on motivational instructional skill needs of teachers for improved teaching. They also disagreed in the same items on motivational instructional skil lneeds of teachers for improved teaching. To further address this research question, hypothesis that there is no significant difference in the mean rating of male and female teachers on the motivational instructional skills needed for improved teaching was tested.

Table 3: Independent t-Test Analysis of Male and Female Teachers on the Motivational Instructional Skills Needed for Improved Teaching (N-1196)

\begin{tabular}{|l|c|c|c|c|c|c|l|}
\hline Gender & $\mathbf{N}$ & $\mathbf{X}$ & $\mathbf{S D}$ & $\mathbf{D f}$ & $\mathbf{t}-\mathbf{c a l}$ & Sig-t & \multicolumn{1}{c|}{ Remark } \\
\hline Male & 579 & 3.31 & .65 & 1194 & 1.54 & 0.12 & $\begin{array}{l}\text { Not } \\
\text { Significant }\end{array}$ \\
\hline Female & 617 & 3.26 & .59 & & & & \\
\hline
\end{tabular}

From Table 3, the calculated t- value at 1194 degree of freedom and 0.05 level of significance is 1.54 . Since the calculated value of $t=1.54$ and is not significant at 0.05 level of significance. This is because -0.12 is greater than 0.05 $(\mathrm{P}=1.54 ; \mathrm{P}>0.05)$. Therefore, the hypothesis is accepted. Hence, there is no significant difference in the mean ratings of male and female teachers on the motivational instructional skills needed for improved teaching in primary schools in Enugu state.

The teachers agreed on the valid motivational instructional skill needs identified in the study. What this means in this findings is that the motivational instructional skill needs are capable of improved teaching in primary schools. Both male and female teachers agreed on the same items on motivational instructional skills needs of teachers for improved teaching. They also disagreed on the same items on motivational instructional skills needs of teachers for improved teaching.

\section{DISCUSSIONS AND CONCLUSIONS}

The result revealed that teachers need to possess the following motivation instructional skills: attributing pupils' successes to their effort; calling pupils by their first names to show sign of recognition; encouraging pupils to always try their best in class work; informing pupils that they can always do well in class work; using gifts to encourage pupils who perform well in class; moving around the class and approach all pupils while teaching; responding positively to incorrect answers, but 
identifying correct part; motivating bright pupils by allowing them to teach other classmates.

The finding is in agreement with the contention of Of ojebe (2010) who reported that some teachers lack motivational skill which is one of the needs for effective teaching. It further revealed that there is significant relationship between teacher motivational skill and students' academic achievement. The results also conform to the earlier findings of Imo, Ekpenyong and Akpan (2014) whose study revealed that teachers need to improve on their motivation skills in order to provide effective teaching for the pupils. And also pupils can be motivated in the classroom through praise, gifts, and allowing the intelligent pupils to teach other classmates. The above finding is not surprising because motivational skills have been reemphasized in many literatures as a correlate of positive educational outcome. It is believed, for instance, that pupils will put more effort when they are praised in class or when their successes is attributed to the effort they have made. Similarly, encouraging pupils to always try their best in class work rather than discouraging them will make them to become serious with their studies.

\section{REFERENCES}

1. Agbo, J.U (2012). Elements of guidance, vocational and career education, Onitsha: Summer Education Publishers (Nig.) Ltd

2. Ali, A. (2009). Conducting research in education and the social sciences. Enugu: Tashiwa Networks.

3. Aluko, U. (2014). Quality instructional outcomes: Teachers' guide. Enugu. Han's publishing.

4. Bot, T.D., \& Binda, S. I. (2013). The roles of parents towards improving the teaching and learning of mathematics for effective entrepreneurial education of students and youths in the society. The International Journal of Educational Studies, 1 (3), 39-47.

5. Bot, T. D. (2014).Examination of teachers' motivational skills for fostering students' interest in learning mathematics in secondary schools in Jos metropolis. International Journal of Innovative Research \& Development 3(1) 75-80.

6. Buchtova, Tereza, et al. "The Concept of Discipline in Novice Teachers in Primary Schools." International Journal of Educational Science and Research (IJESR) 5.1 (2015): 39-48.

7. Decena, Vener D. "Teaching Styles and Competency Levels of Techno-Vocational Teachers at Ramon Magsaysay Technological University: A Development of Competency-Based Assessment Tool for Techno-Vocational Teachers." International Journal of Humanities and Social Sciences (IJHSS) 7.5 (2018).

8. Etudor-Eyo, E., Akpan, C.C. Akuegwu, B.A., \&Bisonog, C.K. (2011).School physical environment and teachers' instructional effectiveness. Journal of OMEP. $7 \& 8$ (1) 117-125.

9. Ifeanyieze, F.O. \&Olaitan, S.O. (2010). Requisite skills required for capacity building of teachers of agriculture for effective teaching of yam production in college of education in South-Eastern Nigeria. Journal of Educational Research10, (1) 81-90.

10. Imo, M. O., Ekpenyoung, O. \&Akpan, I. M. (2014). Teachers' motivational skills as a strategy for enhancing effectiveness in methods of teaching social studies education towards national development in Nigeria: British Journal of Education 2 (1), 31 38: www.ea-journals.org

11. Jacklin, S. \& Lacey, A. (1997). Counselling as instruction for exceptional youths in the universities.Journal of Psychologists, 6(4) 403-409.

12. Keller, E.P. (2011). Gender and science. New York: Peter Bredrick Books.

13. Korpershoek, K. (2008). Teaching motivation of the students in secondary teacher training schools in Turkey, International Journal of Environmental \& Science Education, 3(2), 82 - 88.Press.

14. Liu, E. Z. F. \& Lin, C. H. (2010).The survey study of mathematics motivated strategies for learning questionnaire for grade 10- 
12 Taiwanese students.The Turkish OnlineJournal of Educational Technology, 9 (2), 221-233. 24.

15. Mondy R, Holmes, E, \&Flippo-A.(2011). Influence of motivation on people. http://www.mondy/holmes/flippo.motiv. Retrieved on $3 / 3 / 2014$

16. Morgan, T.C., King, A.R. \& Robinson, M.N. (2008).Theory of human motivation. New York: McGraw-Hill Book Company.

17. Muhammad, R. \&Zaki, M.N. (2010).Effect of cooperative instruction strategy on students performance in Biology. Journal of Theoretical and Empirical Studies in Education, 2, (1), 222-228.

18. Ngwoke, D.U. \&Ngwoke, A.N. (2011). Success and failure of instructional outcomes in public primary schools in Nigeria: teacher attribution. Journal of OMEP7 \& 8, (1) 71-82.

19. Nwanna, J. (2012). Effective strategies for improving primary school pupils' teaching and learning in Enugu State (Master's thesis).University of Nigeria, Nsukka.

20. Obasi, E.O. (2009). Encouraging gender equality secondary education.Journal of Curriculum Studies16 (4) 61-74.

21. Ofojebe, W. N. (2010).Teachers' motivation and its influence on quality assurance in the Nigerian educational system: www.ajol.info

22. Omeke, I. (2014). Assessment of primary school pupils' academic performances in Enugu State (Master's thesis).Kogi State University, Anyimgba

23. Onah, K. (2014). Instructional strategies for improving primary school pupils' academic performance in Enugu State (Master's thesis).Ebonyi State University.

24. Onyeke, L. (2016). Assessment of primary school pupils' academic achievement in Enugu State (Master's thesis), NnamdiAzikiwe University, Awka, Anambra State.

25. Olibie, Eyiuche Ifeoma, Patience Ndidi Egboka, and Wenceslaus Ndubeze Ofojebe. "Secondary Education Policy and Curriculum Provisions in Nigeria: Matters Arising and Enhancement Strategies." International Journal of Library \& Educational Science 3 (1) (2017): 53-66.

26. Rai, Dona. "A Study on Children'S Academic Achievement and Their Curiosity. "International Journal of Humanities and Social Sciences (IJHSS) 7.5 (2018): 39-44.

27. Sinclair, J. (2013). B.B.C. English dictionary. Lagos: Africana Fep publishers.

28. Stears, R.M. \& Porter, L.W. (2008).Motivation and work behaviour. New York: McGraw Hill.

29. Wilen, W., Hutchison, J., \&Ishler, M., (2008).Dynamics of effective secondary teaching. New York: Pearson Education Inc.

30. Zwick, R. (2007). Motive and success.http://www.scu.edu/schools/motivation. Retrieved 6/4/2014 